\title{
Sistem Informasi Manajemen Kinerja Guru
}

\author{
Windy Puji Oktiagraha ${ }^{1}$, Umi Proboyekti ${ }^{2}$, Yetli Oslan ${ }^{3}$ \\ Sistem Informasi, Universitas Kristen Duta Wacana \\ Jl. Dr. Wahidin Sudirohusodo No. 5-25, Yogyakarta \\ windy.pujiesi.ukdw.ac.id \\ 2othiedsi.ukdw.ac.id \\ ${ }^{3}$ yetli@staff.ukdw.ac.id
}

\begin{abstract}
Quality assurance of education is currently considered important for every school. The process that occurs in the quality assurance of education is the assessment of teacher performance. Teachers performance in schools can be assessed based on daily attendance, total teaching hours, and student assessment. In assessing teachers' performance, the school found efficiency problems in the use of cost and time resources because paper printing is the medium of value retrieval and recapitulation in order for the data to be a value. Another problem is the absence of integrated media that supposed to accommodate such assessments into one place.

Based on the situation above, the author created a web-based application for high school with the aim of assisting the teacher performance assessment process. This application is designed to be an integrated data recording, processing and management media for every aspect of teacher performance assessment. The system built will facilitate teachers in conducting presses digitally. In addition, the system can facilitate students in filling out survey forms for teacher assessment. From these data the system will also display grades for each aspect that is useful for the principal for decision making.

The system testing process is based on several scenarios intended for testing respondents. Ten respondents are involved in the testing of system. They consisted of 1 person as the deputy head of the curriculum, the school principal, 7 teachers and 1 person as a student. The final results of this study showed that all respondents in the study successfully performed tasks in the scenarios created.
\end{abstract}

Abstrak- Penjaminan mutu pendidikan saat ini dianggap penting untuk dilakukan oleh setiap sekolah. Proses yang terjadi dalam penjaminan mutu pendidikan ini diantaranya adalah penilaian kinerja guru. Kinerja guru di sekolah dapat dinilai kehadiran harian, total jam mengajar, dan penilaian siswa. Dalam pelaksanaannya, sekolah mendapati permasalahan efisiensi dalam penggunaan sumber daya biaya dan waktu. Datadata yang digunakan sebagai dasar penilaian sebagaianterekam dalam media tercetak. Sebagian lagi dalam format elektronik dan tidak menjadi satu kesatuan. Akses dan pengolahan data-data tersebut menjadi tidak efisien dan membutuhkan waktu banyak. Media terintegrasi yang mampu menampung seluruh penilaian tersebut ke dalam satu tempat belum tersedia.

Dari permasalahan tersebut penulis membuat aplikasi berbasis web untuk sekolah menengah atas dengan tujuan untuk membantu proses penilaian kinerja guru. Aplikasi ini dirancang agar mampu menjadi media pencatatan, pengolahan dan pengelolaan data yang terintegrasi untuk tiap aspek penilaian kinerja guru. Sistem yang dibangun akan memfasilitasi guru dalam melakukan presensi secara digital.Selain itu, sistem dapat memfasilitasi murid dalam mengisi form survei untuk penilaian guru. Dari data-data ini sistem juga akan menampilkan nilai untuk tiap-tiap aspek yang berguna bagi kepala sekolah untuk pengambilan keputusan.

Proses pengujian sistem ini dilakukan berdasarkan beberapa skenario yang ditujukan untuk responden penelitian. Responden

JUTEI Edisi Volume.4 No.2 Oktober 2020

ISSN 2579-3675, e-ISSN 2579-5538

DOI 10.21460/jutei.2020.42.196 pengujian dalam sistem ini berjumlah 10 orang. Adapun responden terdiri dari 1 orang sebagai waka kurikulum, 1 orang sebagai kepala sekolah, 7 orang sebagai guru dan 1 orang sebagai siswa. Hasil akhir dari penelitian ini menunjukkan bahwa seluruh responden dalam penelitian berhasil melakukan task-task dalam skenario yang dibuat.

Kata Kunci-Kinerja Guru, Presensi Digital, E-survey, SMA Bopkri 1 Yogyakarta

\section{Pendahuluan}

Penjaminan mutu pendidikan saat ini dianggap penting bagi sekolah. Salah satu hal yang menjadi bagian penjaminan mutu pendidikan adalah penilaian kinerja guru. Penilaian kinerja guru juga dilakukan pada SMA tempat studi kasus penelitian ini. Kinerja guru di sekolah didasari pada data kehadiran harian, total jam mengajar, dan penilaian siswa. Komponen-komponen tersebut merupakan pendukung dalam proses evaluasi kinerja guru. Evaluasi kinerja guru merupakan prosedur formal yang dilakukan oleh sekolah untuk menilai performa guru [1]. Ini juga memberikan acuan mengenai apa yang harus dilakukan oleh seorang guru agar bisa meningkatkan kinerjanya.

Dalam melakukan penilaian, sekolah memerlukan usaha lebih dan prosedur yang panjang dalam melakukan evaluasi dan menghasilkan laporan penilaian kinerja. Data-data yang digunakan sebagai dasar penilaian sebagaianterekam dalam media tercetak. Sebagian lagi dalam format elektronik dan tidak menjadi satu kesatuan. Akses dan pengolahan data-data tersebut menjadi tidak efisien dan membutuhkan waktu banyak. Media terintegrasi yang mampu menampung seluruh penilaian tersebut ke dalam satu tempat belum tersedia.

Permasalahan tersebut menjadi dasar dari penelitian ini. Penelitian bertujuan untuk membangun sebuah sistem yang menjadi media untuk memperoleh, mengolah, dan mengelola data-data untuk menilai kinerja guru. Data-data tersebut adalah data survei guru untuk penilaian aspek pedagogik guru, dan manajemen kinerja guru untuk penilaian aspek profesional guru. Sistem diharapkan dapat membantu setiap pemangku kebijakan (stakeholder) dalam kegiatan evaluasi guru agar lebih efisien dalam mengambil keputusan.

\section{II.LANDASAN TEORI}

\section{A. Evaluasi Kinerja Guru}

Evaluasi kinerja guru adalah penilaian dari tiap butir kegiatan tugas utama guru dalam rangka pembinaan karir, kepangkatan, dan jabatannya. Pelaksanaan tugas utama guru tidak lepas dari kemampuan dalam penguasaan dan penerapan pengetahuan, ketrampilan serta aspek profesionalisme seperti 
hasil kerja, kehadiran dan ketepatan waktu [2]. Adapun Penilaian Kinerja Guru terbagi menjadi 4 Aspek yang di antaranya adalah:

1) Aspek Pedagogik: Aspek ini merupakan kemampuan guru dalam pemahaman terhadap perserta didik, perancangan dan penerapan strategi belajar-mengajar sehigga dapat mendukung perkembangan peserta didik.

2) Aspek Sosial: Merupakan kemampuan guru untuk berkomunikasi dan berinteraksi secara baik dengan peserta didik, sesama tenaga pendidik, orang tua/wali peserta didik, dan masyarakat sekitar. Komunikasi yang dimaksud adalah komunikasi secara lisan maupun tulisan

3) Aspek Kepribadian: Aspek ini merupakan kemampuan personal guru dalam mencerminkan kepribadian yang mantap, stabil, dewasa, arif dan berwibawa. Komponen ini mengacu pada kepatuhan guru terhadap norma yang ada. Ini bermaksud agar guru dapat menjadi media percontohan dan teladan bagi peserta didik.

4) Aspek Profesional : Aspek ini merupakan kemampuan Guru dalam melaksanakan tugas utamanya. Komponen yang ada didalamnya yaitu kemampuan guru dalam menjalankan kegiatan belajar-mengajar, penggunaan waktu yang efisien, pemanfaatan peralatan sebagai pendukung, kehadiran, ketepatan waktu, serta penugasan tertentu untuk guru.

Kemampuan guru untuk memenuhi tiap aspek penilaian kinerja tersebut tentunya akan berpengaruh pada kualitas mutu tenaga pengajar pada tiap sekolah. Evaluasi kinerja guru merupakan kegiatan yang dilakukan untuk mengukur tingkat kemampuan tiap guru dalam melaksanakan tugas utama yang ditunjukkan melalui untuk kinerjanya. Evaluasi kinerja guru merupakan prosedur formal yang dilakukan oleh sekolah untuk menilai performa guru. Ini juga memberikan acuan mengenai apa yang harus dilakukan oleh seorang guru agar bisa meningkatkan kinerjanya [3]. Melalui evaluasi, sekolah dapat menentukan keputusan yang tepat untuk tiap guru dan diharapkan akan menghasilkan tenaga pengajar yang profesional, yang tentunya berpengaruh terhadap peningkatan mutu pendidikan.

\section{B. Presensi Elektronik}

Presensi elektronik merupakan cara untuk mengukur kehadiran dan ketepatan waktu pegawai dengan menggunakan peralatan elektronik. Presensi elektronik dilaksanakan oleh pegawai sebelum pelaksanaan apel masuk kerja dan pada saat apel pulang kerja. Penerapan presensi elektronik ini bertujuan untuk mempermudah pelaporan dalam komponen kehadiran dan ketepatan waktu pegawai. Ini dikarenakan komponen tersebut berpengaruh terhadap tingkat kinerja dan profesionalisme tiap pegawai.

Presensi elektronik diterapkan untuk mempermudah pencatatan, pengolahan, dan pengelolaan presensi. Hal yang menjadi acuan dalam penggunaan Presensi elektronik adalah kemampuannya untuk melakukan pencatatan secara spesifik terhadap jam pegawai masuk dan jam pegawai tersebut pulang. Ini diharapkan mampu mendukung dalam penilaian tingkat disiplin tiap pegawai secara lebih terperinci.
Penerapan presensi elektronik juga bertujuan untuk menghindari adanya pelanggaran/kecurangan pada tanda tangan dan pencatatan waktu presensi. Ini bertujuan untuk mendukung Undang - Undang No.43 Tahun 1999 Tentang Perubahan Atas Undang - Undang No.8 Tahun 1974 Tentang Pokok-Pokok Kepegawaian bahwa akan ada sanksi apabila ditemukan keharusan yang tidak dituruti, atau larangan yang dilanggar. Aturan ini bermaksud untuk menjamin tata-tertib dan kelancaran pelaksanaan tugas untuk tiap Pegawai Negeri Sipil, dimana tiap Pegawai Negeri Sipil harus berlaku disiplin dan menaati peraturan yang telah ditetapkan pemerintah.

\section{C.Elektronik Survei}

Elektronik survei merupakan metode pengumpulan data melalui serangkaian pertanyaan yang disajikan melalui media elektronik seperti komputer [4]. Media penyajian kuesioner untuk survei umumnya menggunakan Web browser. Ini dikarenakan web browser mendukung HTML yang dapat dibuat secara interaktif sehingga dapat lebih mudah dipahami oleh pengguna.

Ada beberapa keuntungan dalam penggunaan media elektronik dalam pelaksanaa survei yang diantaranya adalah efesiensi waktu, biaya, serta tenaga. Ini karena semua proses dapat dilakukan secara sistematis dan otomatis menggunakan perangkat elektronik

Penggunaan perangkat elektronik juga dapat berguna bagi pemangku kepentingan (stakeholder) untuk fleksibel dalam menentukan target. Target dapat diatur menjadi lebih luas atau lebih spesifik tergantung pada jenis survei dan target responden.

\section{D.Sistem Informasi Manajemen}

Sistem informasi manajemen merupakan serangkaian sistem dan prosedur yang mampu mengumpulkan dan mengelola data dari berbagai sumber, kemudian melaporkannya dalam bentuk yang mudah dibaca [5]. Setiap pemangku kepentingan (stakeholder) dapat menggunakan sistem informasi manajemen untuk membuat laporan secara komprehensif dan memanfaatkannya sebagai acuan pengambilan kebijakan.

Sistem informasi manajemen terbangun dari komponenkomponen: hardware, software, database, prosedur dan personil. Hardware termasuk CPU, storage, perangkat input/output, terminal untuk interaksi serta media komunikasi data. Software, merupakan pendukung agar komponen hardware dapat digunakan dengan maksimal. Komponen ini termasuk sistem operasi maupun aplikasi sistem. Database merupakan media penyimpanan data yang terintegrasi dan saling berelasi untuk mendukung berjalannya proses bisnis. Prosedur adalah langkah-langkah dalam penggunaan sistem yang terdokumentasi. Personil adalah pihak yang akan menggunakan sistem.

\section{E. SDLC - Waterfall Model}

Model waterfall [6] termasuk ke dalam model generic pada rekayasa perangkat lunak dan pertama kali diperkenalkan oleh Winston Royce sekitar tahun 1970. Model ini melakukan pendekatan secara sistematis dan berurutan pada sistem yang akan dibangun. Disebut dengan waterfall karena setiap tahap yang dilalui harus menunggu selesainya tahap sebelumnya dan berjalan berurutan seperti pada Gambar 1 . 


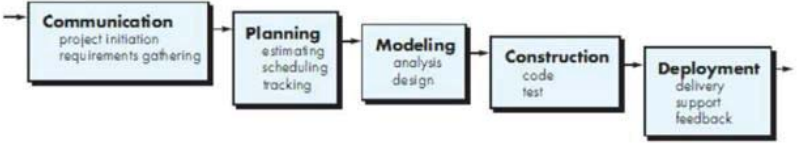

Gambar 26 Fase-fase Waterfall Model

1. Communication (Project Initiation \& Requirement Gathering)

Komunikasi dengan klien sangat diperlukan sebelum melakukan pekerjaan teknis, dengan tujuan memahami tujuan yang diinginkan. Salah satu bentuk komunikasi adalah dengan melakukan wawancara atau observasi. Hasil dari komunikasi tersebut adalah inisialisasi proyek, seperti menganalisis permasalahan yang dihadapi dan mengumpulkan data-data yang diperlukan.

2. Planning (Estimating, Scheduling, Tracking)

Tahapan ini yang menjelaskan tentang estimasi tugastugas teknis yang akan dilakukan, resiko-resiko yang dapat terjadi, sumber daya yang diperlukan dalam membuat sistem, produk kerja yang ingin dihasilkan, penjadwalan kerja yang akan dilaksanakan, dan tracking proses pengerjaan sistem.

\section{Modeling (Analisist \& Design)}

Tahap ini menjelaskan perancangan dan permodelan arsitektur sistem yang berfokus pada perancangan struktur data, arsitektur software, tampilan interface, dan algoritma program. Tujuannya untuk lebih memahami gambaran besar dari apa yang akan dikerjakan.

\section{Construction (Code \& Test)}

Tahapan Construction ini merupakan proses penerjemahan bentuk desain menjadi kode atau bentuk/bahasa yang dapat dibaca oleh mesin. Setelah pengkodean selesai, dilakukan pengujian terhadap sistem dan juga kode yang sudah dibuat. Tujuannya untuk menemukan kesalahan yang mungkin terjadi untuk nantinya diperbaiki.

5. Deployment (Delivery, Support, Feedback)

Tahapan Deployment merupakan tahapan implementasi software ke customer, pemeliharaan software secara berkala atau maintenance, perbaikan software, evaluasi software, dan pengembangan software berdasarkan umpan balik yang diberikan dari pengguna agar sistem dapat tetap berjalan dan berkembang sesuai dengan fungsinya.

\section{Metode Penelitian}

\section{A. Tahapan Dalam SDLC}

1) Communication (Project Initiation \& Requirements Gathering): Metode yang digunakan untuk memperoleh data adalah dengan melakukan komunikasi dengan calon pengguna. Salah satu bentuk komunikasi adalah dengan melakukan wawancara dan observasi dengan setiap pemangku kebijakan di SMA Bopkri 1 Yogyakarta.

Wawancara melibatkan 4 pemangku kebijakan yang merupakan subyek utama dalam penelitian. Pemangku kebijakan ini terdiri dari 1 orang kepala sekolah, 1 orang waka kurikulum, 7 orang guru dan 1 orang siswa. Wawancara ini memberikan representasi tentang evaluasi kinerja guru dari sudut pandang setiap pemangku kebijakan.

Proses observasi dilakukan di SMA Bopkri 1 Yogyakarta. Observasi dilakukan untuk melihat proses presensi guru, pengisian form survei oleh siswa dan proses rekapitulasi laporan kinerja guru. Observasi ini menghasilkan data berupa data presensi harian guru, presensi mengajar guru, form survei guru dan metode perhitungan nilai survei guru.

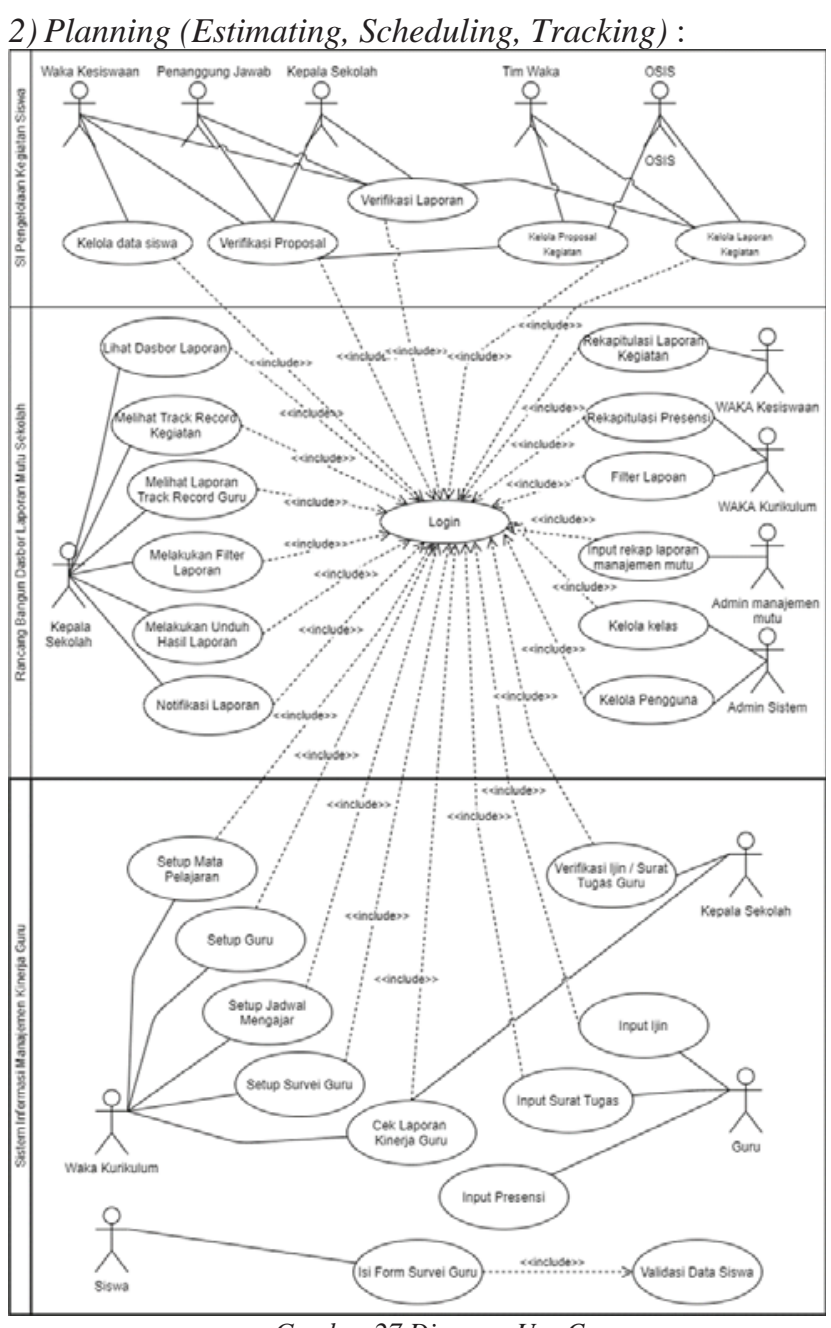

Gambar 27 Diagram Use Case

Dari use case pada Gambar 27, setiap aktor memiliki peran dan kemampuan masing-masing. Dalam rancangan sistem ini terdapat beberapa fungsi yang dapat dijalankan oleh satu atau lebih dari satu aktor.

Setiap aktor dalam sistem ini memiliki tugas dan fungsinya masing-masing. Fungsi-fungsi dalam sistem ini dbuat agar tidak semua dapat diakses dalam satu waktu. Terdapat batasan hak akses untuk tiap-tiap aktor agar input sistem tidak dapat dilakukan secara sembarangan. Oleh karena itu, setiap fungi dalam sistem akan dibatasi dengan fungsi login sebagai verifikasi hak akses dalam sistem. 
3) Modeling (Analysis \& Design) :

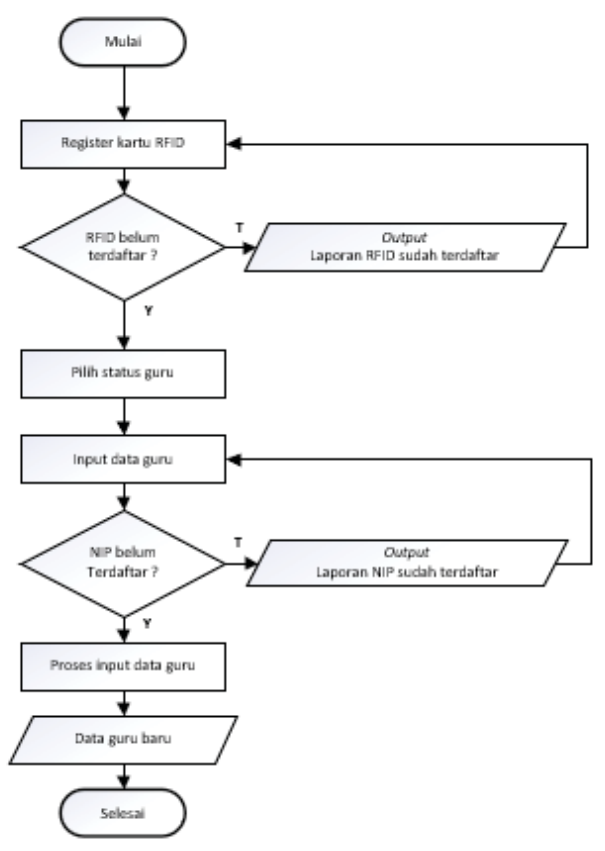

Gambar 28 Flowchart Setup Guru

Dari Gambar 28 dapat dilihat bahwa penambahan guru baru diawali dengan proses register kartu RFID sebagai input utama dalam proses presensi. Pada tahap ini dilakukan pemeriksaan untuk memastikan bahwa kartu RFID belum digunakan oleh guru lain. Apabila kartu RFID belum terdaftar, maka akan dilanjutkan ke proses pemilihan status guru. Tahap selanjutnya adalah dengan memasukkan data guru pada formulir yang telah disediakan dalam sistem. Pada proses ini juga dilakukan pemeriksaan kembali pada data NIP guru. Ini bertujuan untuk memastikan bahwa tidak ada duplikasi NIP guru. Selain memang harus unik, NIP akan digunakan sebagai username untuk login guru. Apabila proses penambahan guru selesai, Waka Kurikulum dapat keluar dari sistem dengan melakukan logout.

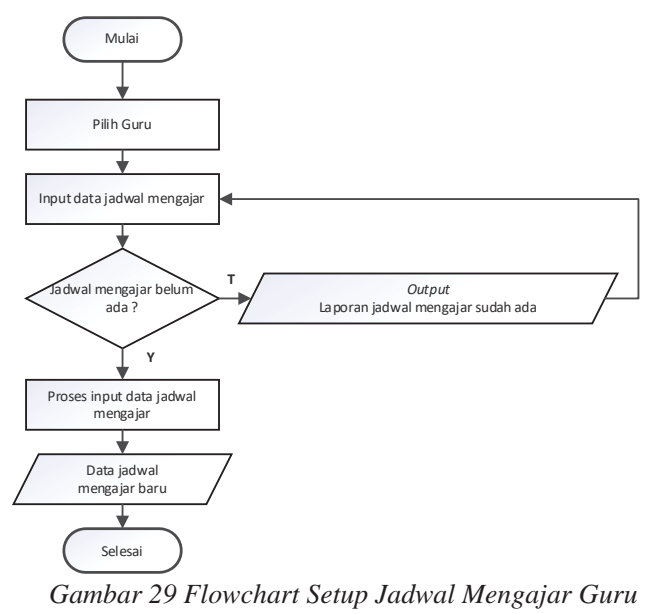

Flowchart pada Gambar 29 menjelaskan bahwa proses penambahan jadwal mengajar guru dimulai dari pemilihan data guru. Proses selanjutnya adalah dengan menambahkan data mata pelajaran yang akan diampu oleh guru. Apabila data jadwal mengajar sudah ada maka akan ada notifikasi bahwa data sudah ada dan data tidak akan disimpan. Namun jika data jadwal mengajar belum tersedia maka data jadwal mengajar akan disimpan ke dalam sistem.

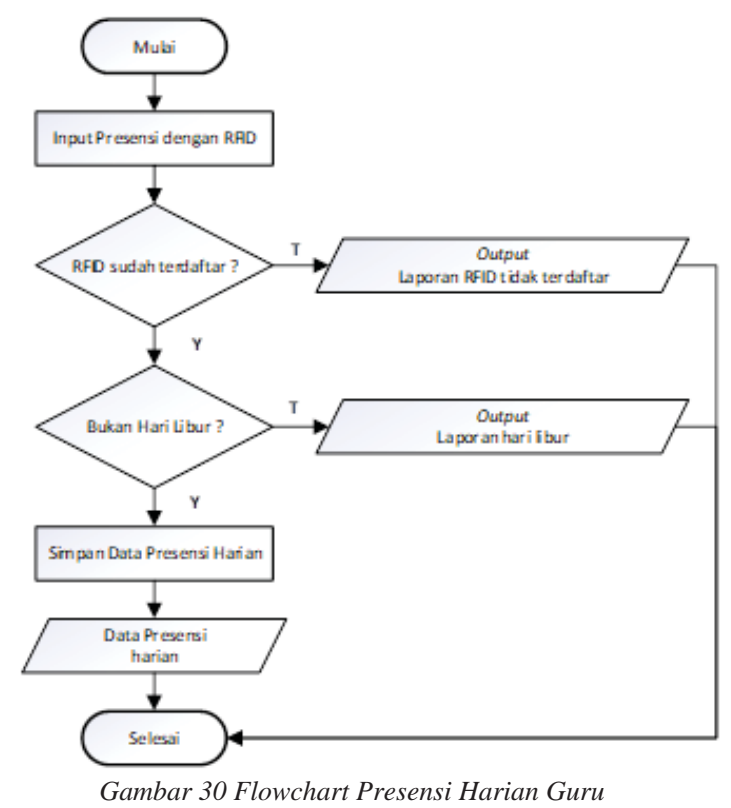

Seperti yang terlihat pada Gambar 30 bahwa proses diawali dengan guru melakukan input presensi menggunakan RFID. Apabila RFID belum terdaftar maka akan muncul notifikasi bahawa RFID belum terdaftar dan presensi tidak dapat disimpan. Namun apabila RFID sudah terdaftar maka akan dilanjutkan pada proses selanjutnya yaitu pemeriksaan hari libur. Proses selanjutnya apabila tidak ditemukan libur pada hari yang bekaitan maka presensi akan disimpan.

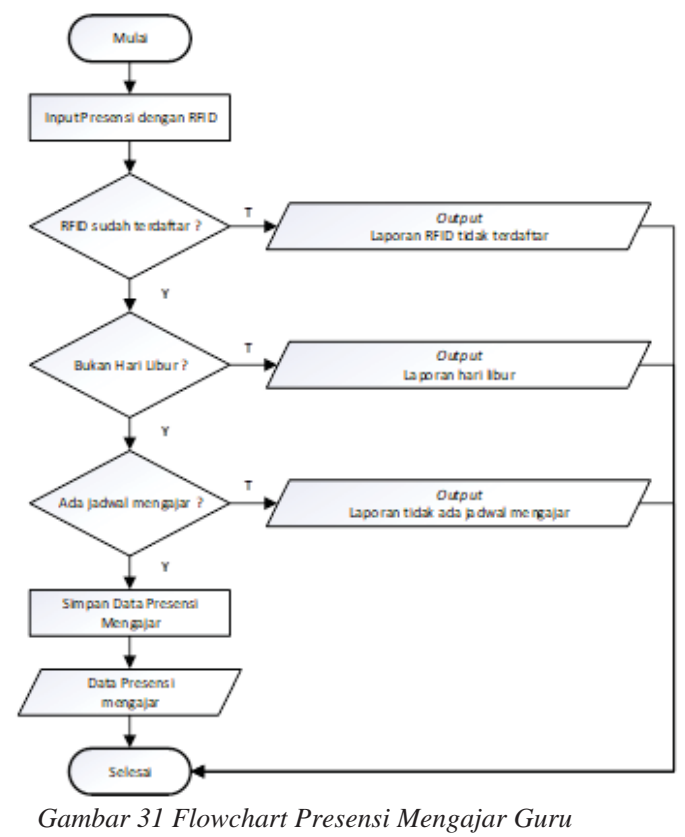

Flowchart pada Gambar 31 menjelaskan bahwa proses input presensi mengajar dimulai dari pemeriksaan kartu RFID yang digunakan. Apabila kartu RFID tidak terdaftar maka akan muncul notifikasi bahwa kartu tidak terdaftar dan data tidak akan disimpan ke dalam sistem. Namun jika RFID 
terdaftar maka akan dilanjutkan ke proses selanjutnya yaitu pemeriksaan tanggal libur. Pada proses ini akan dicari apakah ada libur pada tanggal yang berkaitan. Apabila tidak ditemui hari libur maka proses akan dilanjutkan pada pemeriksaan jadwal mengajar pada waktu guru melakukan presensi. Apabila tidak ada jadwal mengajar ditemukan pada jam yang berkaitan maka akan muncul notifikasi bahwa jam mengajar tidak ditemukan dan presensi mengajar tidak akan disimpan. Namun jika ditemukan jadwal mengajar maka data presensi mengajar akan disimpan ke dalam sistem.

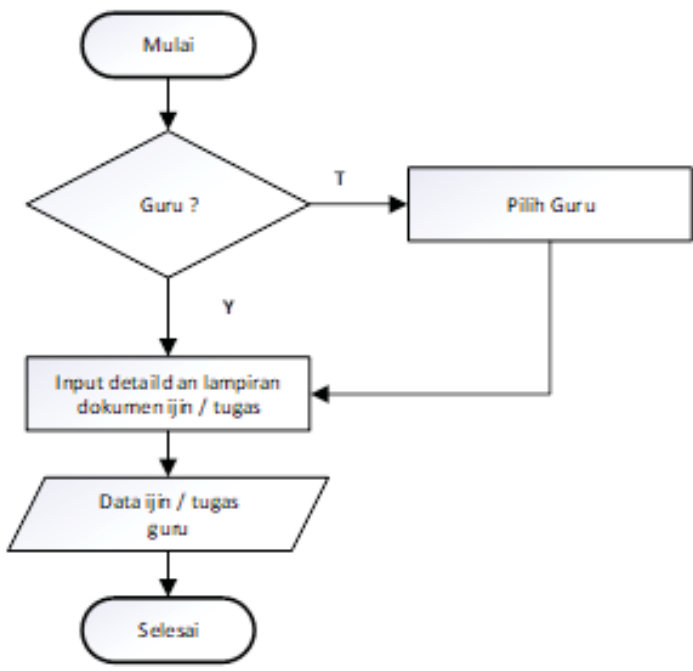

Gambar 32 Flowchart Pengajuan Ijin Guru

Seperti yang terlihat pada Gambar 32 bahwa proses pengajuan ijin atau surat tugas guru dimulai dari pemeriksaan pengguna yang mengajukan. Apabila guru mengajukan ijin secara langsung maka guru dapat langsung memilih jenis ijin yang diajukan. Namun jika ijin diajukan oleh waka kurikulum maka diperlukan proses pemilihan guru terlebih dahulu. Proses selanjutnya adalah melakukan pencatatan detil libur dan lampiran bukti ijin pendukung

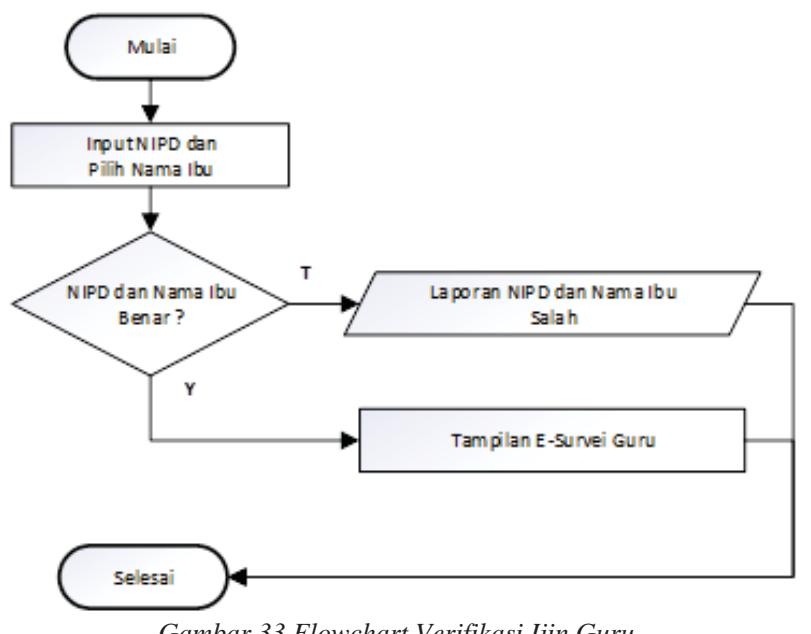

Gambar 33 Flowchart Verifikasi Ijin Guru

Seperti yang terlihat pada Gambar 33 bahwa proses verifikasi ijin guru dimulai dari proses memilih daftar pengajuan yang ada. Proses selanjutnya adalah pencatatan keputusan oleh kepala sekolah terhadap pengajuan ijin/ surat

JUTEI Edisi No.2 Volume.4 Oktober 2020

ISSN 2579-3675, e-ISSN 2579-5538

DOI 10.21460/jutei.2020.42.196 tugas yang dipilih. Terdapat dua keputusan yang dapat dibuat oleh kepala sekolah terhadap pengajuan ijin/ surat tugas yang dipiih. Adapun keputusan tersebut adalah disetujui dan tidak disetujui. Keputusan tersebut selanjutnya akan disimpan ke dalam sistem

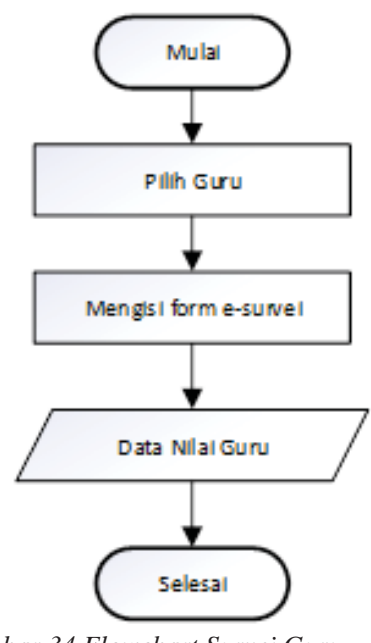

Gambar 34 Flowchart Survei Guru

Flowchart pada Gambar 34 Menjelaskan tentang proses pengisian form e-survey oleh siswa. Proses ini diawali dari siswa memilih guru untuk disurvei. Proses selanjutnya adalah siswa mengisi form $e$-survey yang berisi pilihan ganda maupun masukan. Hasil survei kemudian akan disimpan ke dalam sistem dan menghasilkan data nilai guru

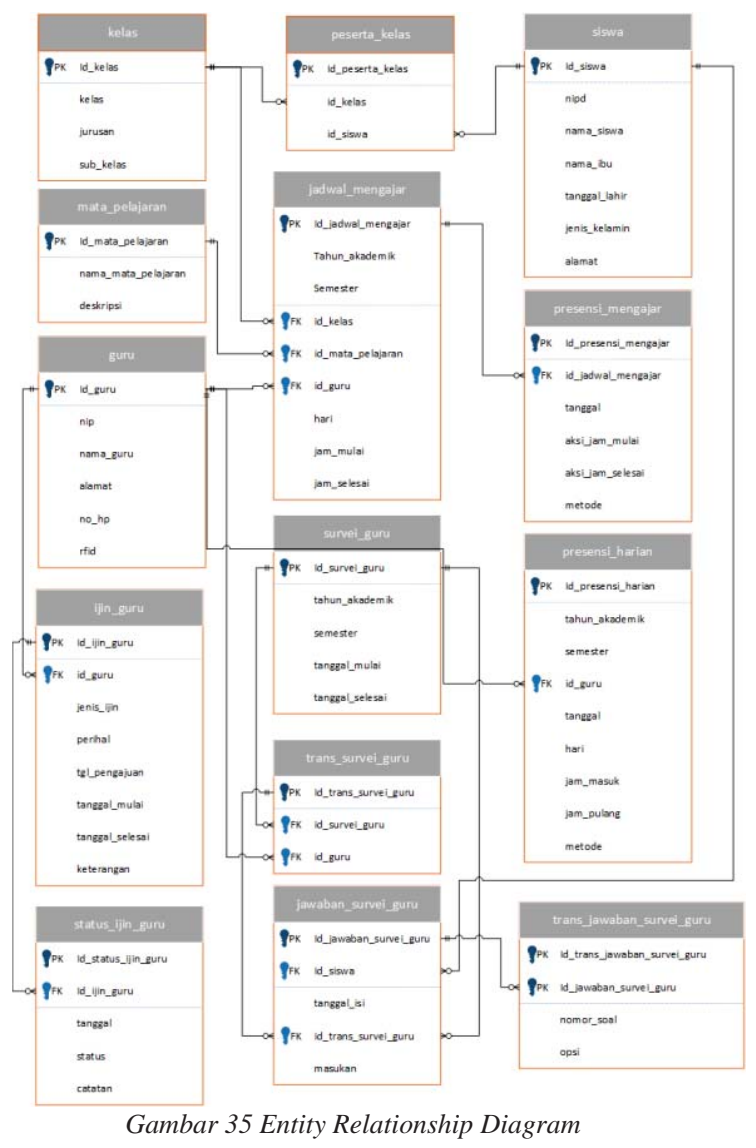

Entity Relationship Diagram (ERD) pada Gambar 35 merupakan diagram yang merepresentasikan hubungan antara 
objek-objek data dalam sistem yang akan dibangun. Setelah dibuat rancangan tabel database, proses selanjutnya adalah merancang proses untuk aliran data dalam sistem.

Data Flow Diagram merupakan salah satu alat bantu untuk menjelaskan atau menggambarkan bagaimana data mengalir. Melalui data flow diagram dapat diketahui dari mana data berasal, bentuk masukan, proses yang terjadi dan bentuk keluaran.

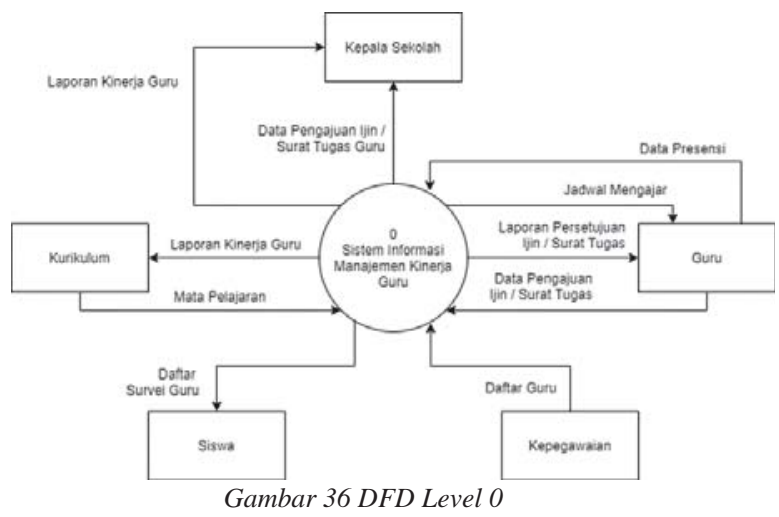

Data flow diagram level 0 pada Gambar 36 merupakan gambaran keseluruhan tentang aliran data masuk dan data keluar pada Sistem Informasi Kinerja Guru. Sistem akan berhubungan dengan 5 entitas yang diantaranya adalah Kurikulum, Siswa, Kepegawaian, Guru, dan Kepala Sekolah. Tiap entitas pada sistem akan berkaitan satu sama lain. Adapun data yang dibutuhkan dalam sistem ini adalah data mata pelajaran yang diambil dari entitas Kurikulum, data guru yang diperoleh dari entitas kepegawaian, serta data presensi dan pengajuan ijin yang diambil dari entitas guru. Secara umum sistem akan menghasilkan informasi jadwal mengajar dan laporan persetujuan ijin/surat tugas bagi guru. Selain itu, sistem juga akan menghasilkan laporan informasi kinerja guru yang dapat diberikan kepada Kurikulum dan Kepala Sekolah.

Proses selanjutnya dibuat dengan melakukan desain input yang akan digunakan oleh siste. Desain ini merupakan rancangan awal sebagai acuan dalam pembuatan sistem. Pada sistem ini proses penambahan guru dilakukan oleh Waka Kurikulum. Rancangan halaman untuk tiap-tiap proses dalam sistem dijabarkan dalam rangkaian penjelasan berikut ini.

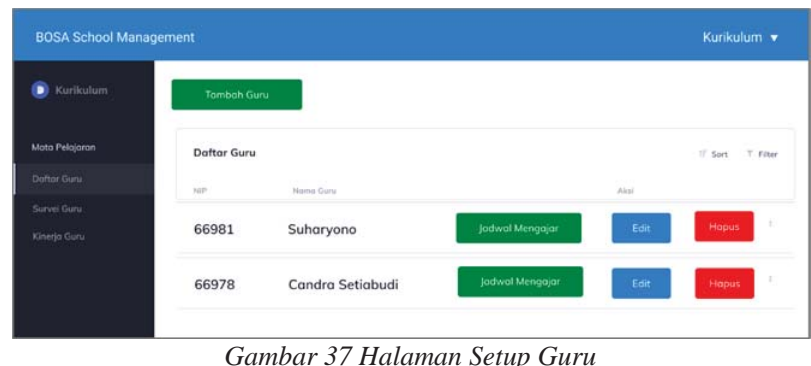

Pada Gambar 37 dibuat rancangan mengenai halaman setup guru. Halaman ini berfungsi untuk meregistrasikan data guru ke dalam sistem. Proses yang dapat dilakukan pada halaman ini adalah tambah guru, penambahan jadwal mengajar guru, edit data guru dan hapus guru

Setelah rancangan setup guru, pada Gambar 38 dirancang sebuah halaman setup jadwal mengajar guru. Penambahan ini berfungsi dalam proses validasi jadwal ketika guru melakukan presensi. Proses yang dapat dilakukan admin dalam proses ini adalah memilih hari, kelas, mata pelajaran, jam mulai dan jam selesai guru mengajar.

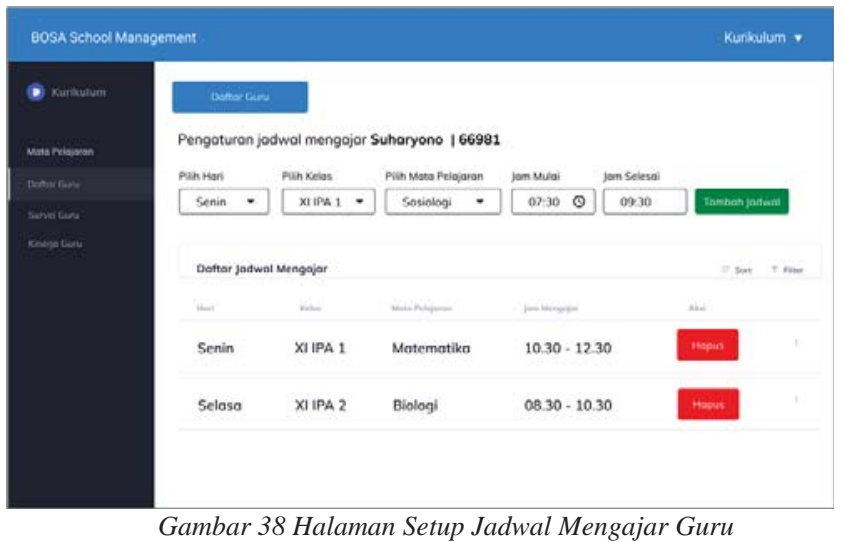

Setelah rancangan setup jadwal mengajar. Pada Gambar 39 dibuat sebuah rancangan halaman presensi mengajar guru. Pada halaman ini akan terhubung sebuah sistem RFID sehingga pengguna cukup menempelkan kartu RFID dan presensi akan tercatat ke dalam sistem. Halaman ini kemudian akan menampilkan informasi mengenai jam presensi yang tercatat ke dalam sistem kepada guru

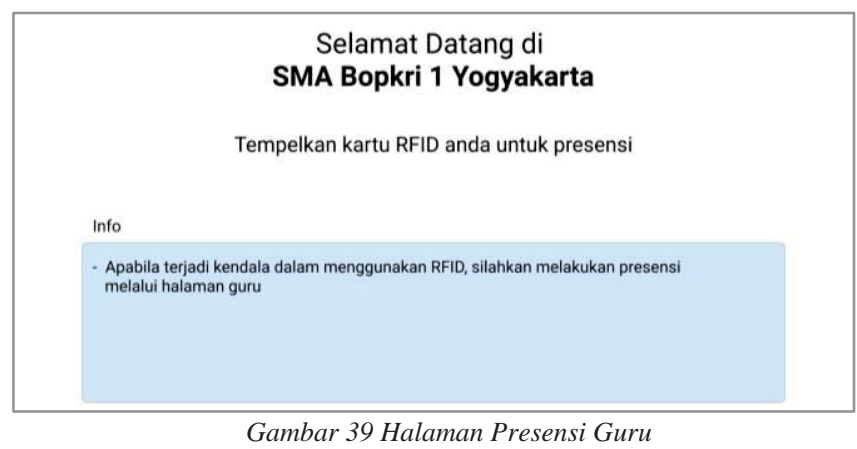

4) Construction (Code \& Test): Sistem yang dibangun dirancang dengan menggunakan bahasa pemrograman PHP dengan framework Codeigniter. Secara umum, Codeigniter menerapkan Model, View, Controller (MVC) sebagai standar penulisannya. Berikut adalah salah satu contoh cara penggunaan Framework Codeigniter: 


\section{Sistem Informasi Manajemen Kinerja Guru}

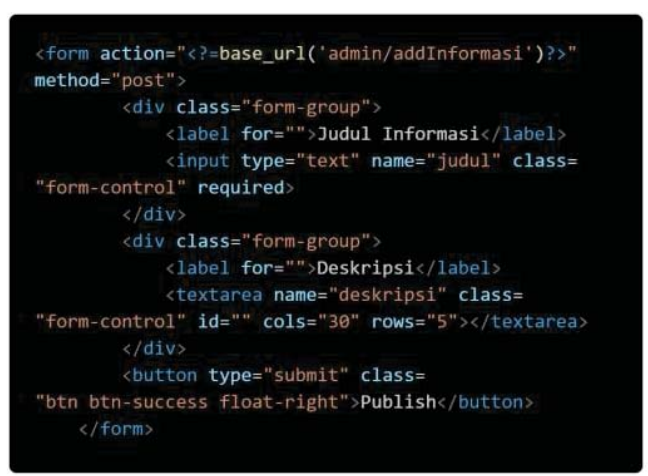

Gambar 40 View Codeigniter

Pada Gambar 40 merupakan contoh penggunaan form untuk penambahahan informasi pada sistem. Form kemudian dikirimkan ke controller sebelum disimpan di database.

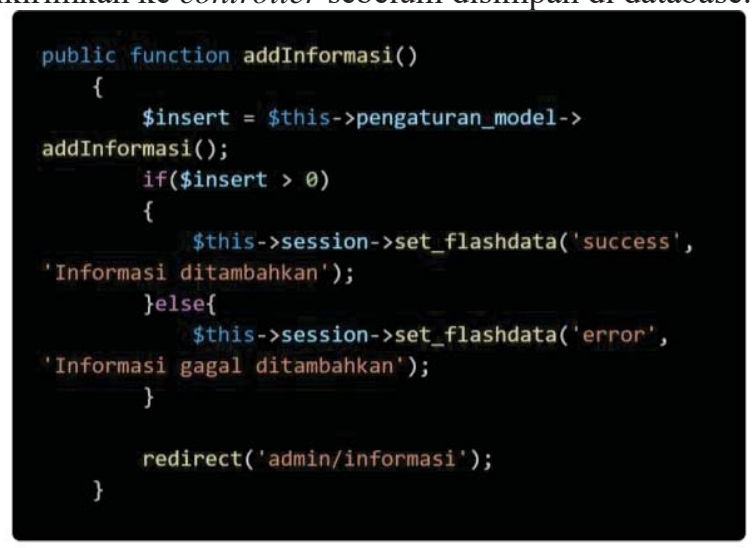

Gambar 41 Controller Codeigniter

Pada Gambar 41 merupakan fungsi pada controller yang menerima post dari form di view. Fungsi ini bertugas untuk mengirim ke model untuk disimpan di database.

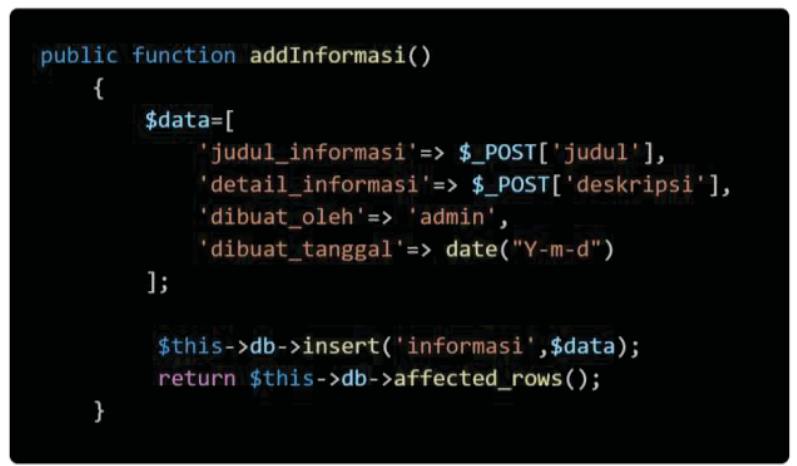

Gambar 42 Model Codeigniter

Model pada Gambar 42 ini data dari post diterima dari controller untuk kemudian disimpan. Fungsi ini kemudian akan mengembalikan sebuah parameter untuk memberikan informasi keberhasilan menyimpan data

\section{B. Analisis Data}

Data yang digunakan adalah data guru, presensi, ijin, tugas dan nilai hasil survei guru. Data guru digunakan sebagai data awal dalam pembuatan sistem. Sedangkan data presensi akan digunakan dalam pengambilan nilai kehadiran harian. Selain itu, data presensi mengajar juga akan digunakan sebagai perhitungan total jam mengajar guru. Data terakhir adalah data survei sebagai data penilaian siswa terhadap guru.

\section{ANALISIS DAN HASIL}

\section{A. Profil Pengguna}

Penelitian terhadap sistem informasi manajemen kinerja guru ini melibatkan beberapa responden dengan tugas dan fungsi yang berbeda-beda. Total responden dalam pengujian ini berjumlah 10 orang. Responden terbagi menjadi 4 yaitu 7 orang sebagai guru, 1 orang sebagai waka kurikulum, 1 orang sebagai kepala sekolah dan 1 orang sebagai siswa.

\section{B. Implementasi Sistem}

Bagian ini akan menjelaskan hasil implementasi dari aplikasi yang telah dibuat. Implementasi ini mengacu dari rancangan yang telah dibuat sebelumnya. Dalam implementasi, terdapat beberapa penyesuaian ulang agar sistem dapat lebih sesuai dengan kebutuhan. Berikut ini adalah rangkaian tampilan antarmuka sistem.

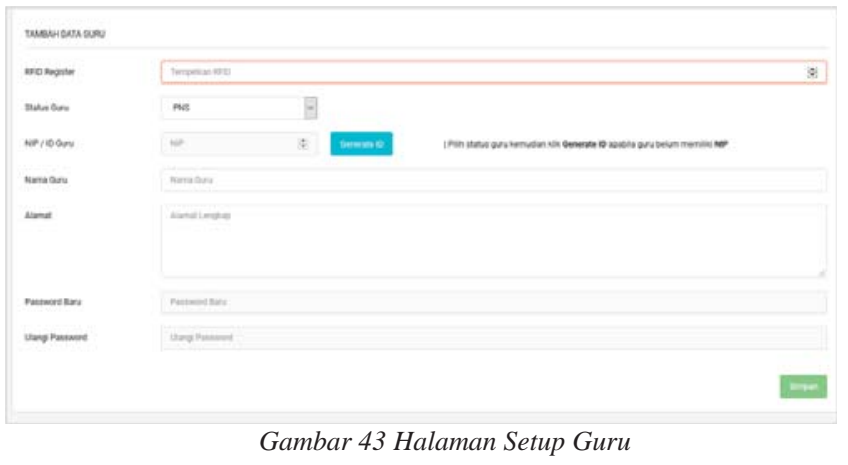

Pada Gambar 43 merupakan hasil implementasi form untuk penambahan data guru. Pada form ini user dapat menambahkan data guru seperti RFID untuk presensi dan data diri guru lainnya. Apabila guru belum memiliki NIP maka dapat dibuatkan NIP atau ID sementara dengan menekan tombol generate di sebelah kolom NIP yang sudah disediakan.

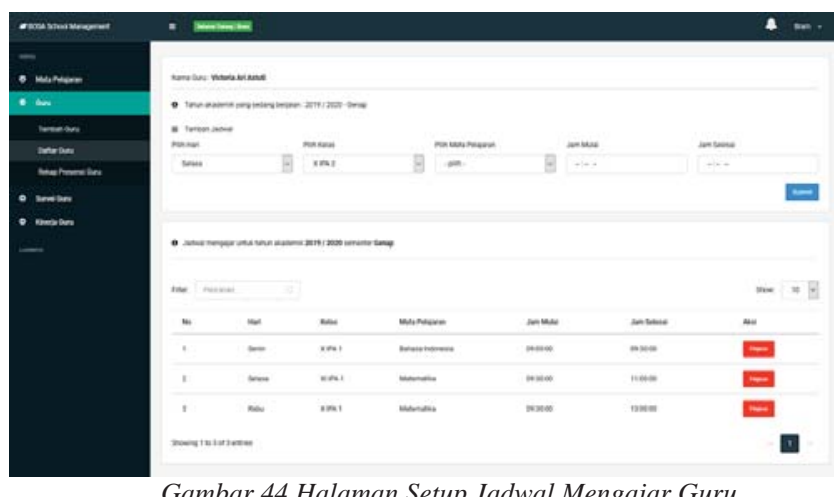

Pada Gambar 44 merupakan hasil implementasi halaman penambahan jadwal mengajar guru. Penambahan ini berfungsi dalam proses validasi jadwal ketika guru melakukan presensi. Proses yang dapat dilakukan admin dalam proses ini adalah memilih hari, kelas, mata pelajaran, jam mulai dan jam selesai guru mengajar. 


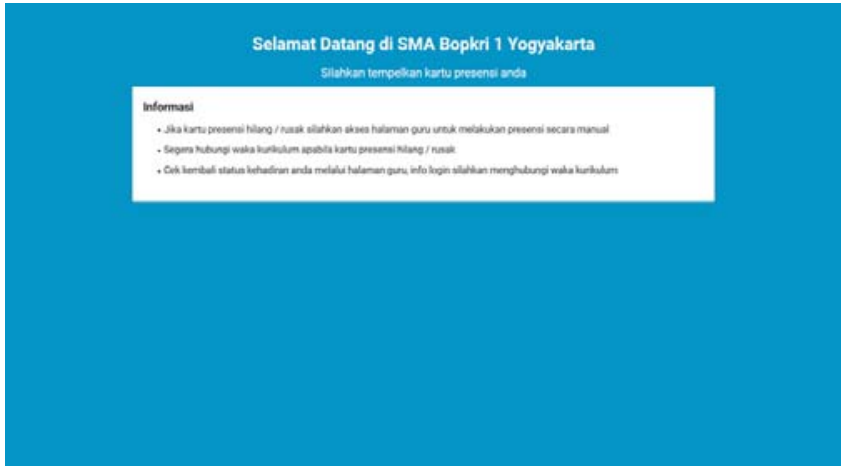

Gambar 45 Halaman Presensi Harian Guru dengan RFID

Pada Gambar 45 merupakan hasil implementasi halaman presensi harian guru. Pada halaman ini terhubung sebuah sistem RFID sehingga pengguna cukup menempelkan kartu RFID dan presensi akan tercatat ke dalam sistem. Halaman ini kemudian akan menampilkan informasi mengenai jam presensi yang tercatat ke dalam sistem kepada guru

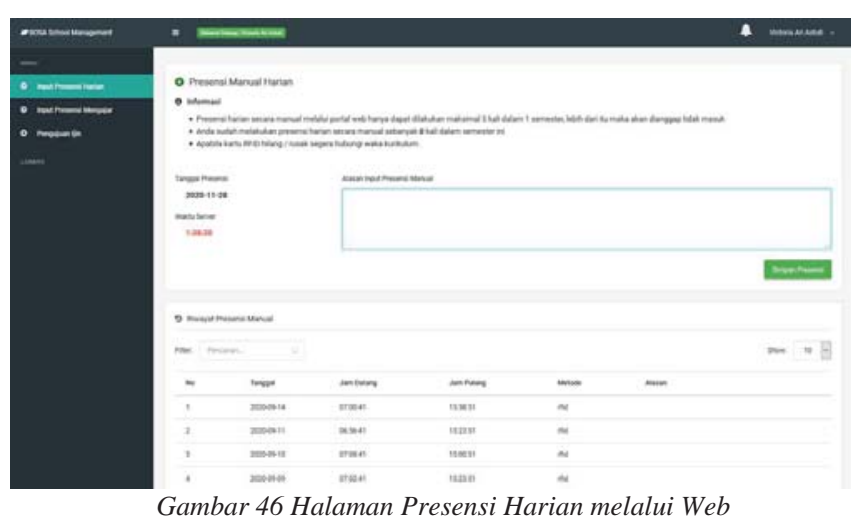

Pada Gambar 46 merupakan hasil implementasi rancangan halaman presensi harian guru melalui web. Halaman ini memungkinkan pengguna untuk dapat tetap melakukan presensi secara digital meskipun terjadi gangguan pada presensi RFID. Pada halaman ini pengguna juga dapat melihat riwayat presensi harian yang sudah dilakukan dalam satu semester

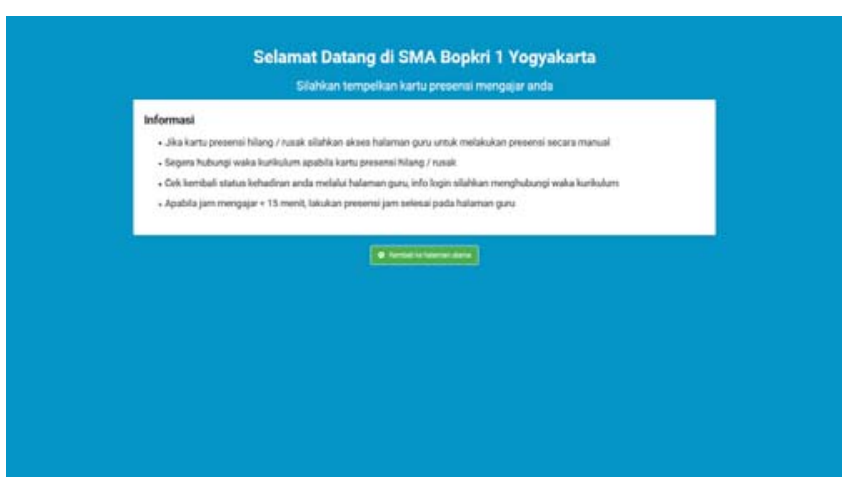

Gambar 47 Halaman Presensi Mengajar Guru dengan RFID

Pada Gambar 47 merupakan hasil implementasi rancangan halaman presensi mengajar guru. Pada halaman ini terhubung sebuah sistem RFID sehingga pengguna cukup menempelkan kartu RFID dan presensi akan tercatat ke dalam sistem.
Halaman ini kemudian akan menampilkan informasi mengenai jam presensi yang tercatat ke dalam sistem kepada guru

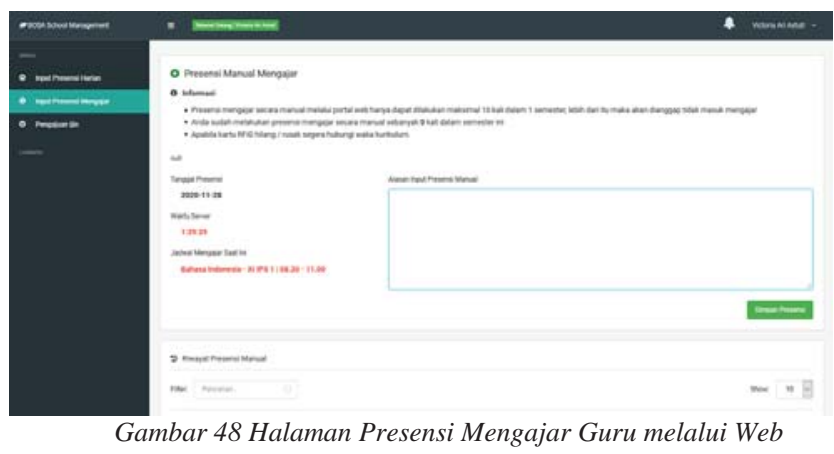

Pada Gambar 48 merupakan hasil implementasi rancangan halaman presensi mengajar guru melalui web. Halaman ini memungkinkan pengguna untuk dapat tetap melakukan presensi secara digital meskipun terjadi gangguan pada presensi RFID. Pada halaman ini pengguna juga dapat melihat riwayat presensi mengajar yang sudah dilakukan dalam satu semester.

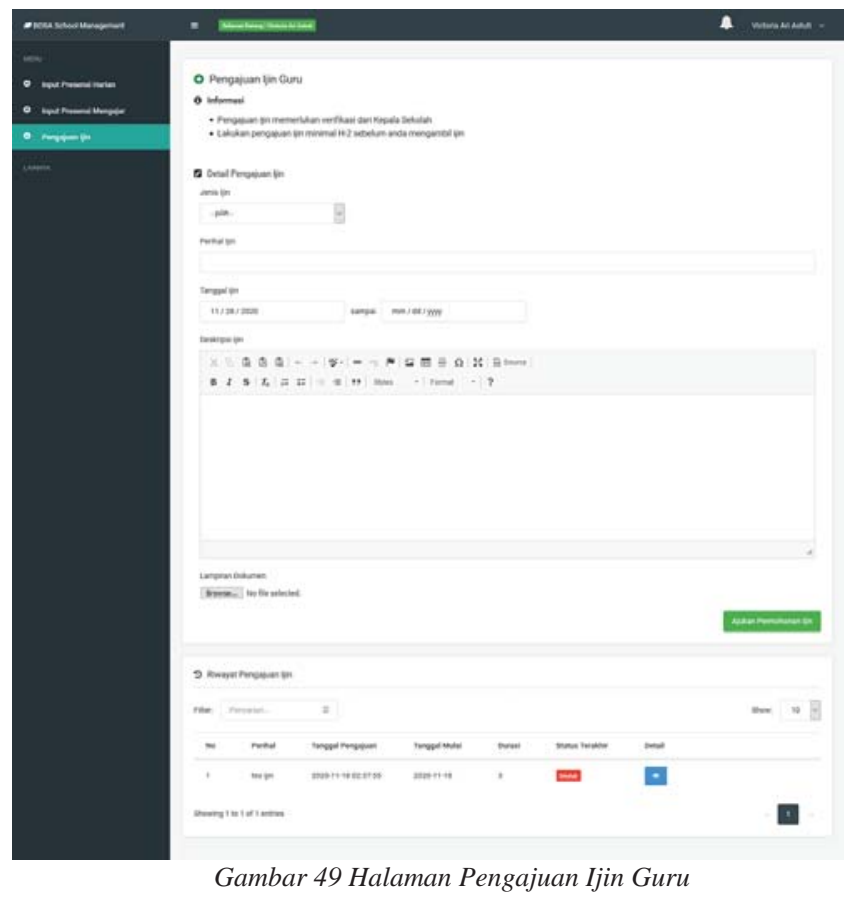

Pada Gambar 49 merupakan hasil implementasi halaman ijin yang memungkinkan guru untuk dapat mengajukan ijin secara digital. Pada halaman ini pengguna dapat melakukan pengajuan ijin, perubahan ijin dan pembatalan ijin yang belum terverifikasi oleh kepala sekolah. 


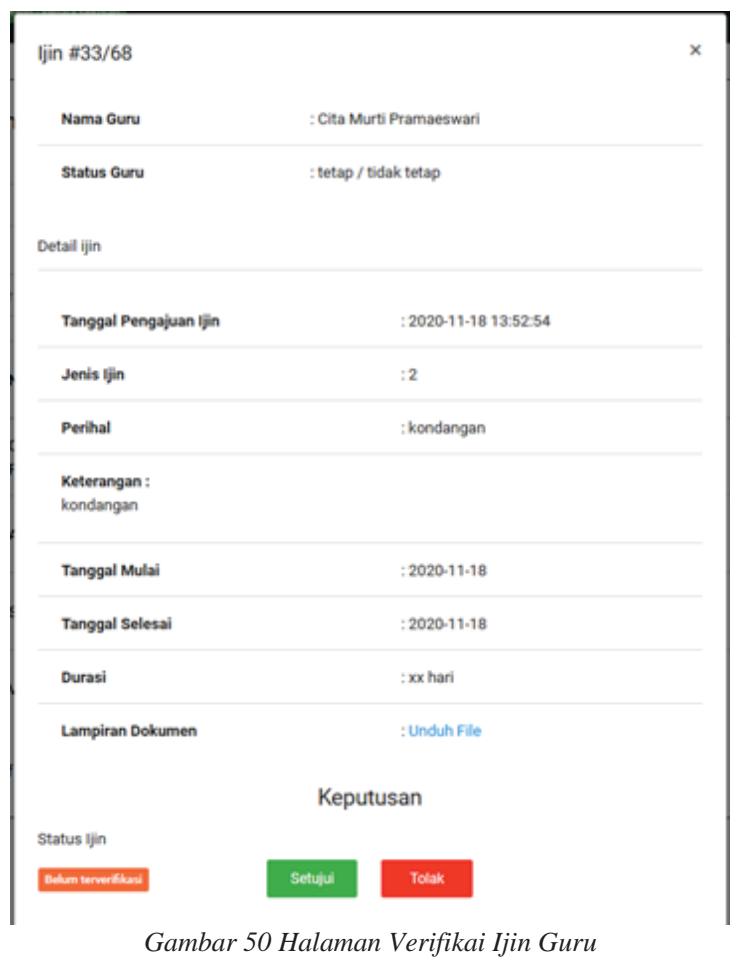

Pada Gambar 50 merupakan hasil implementasi tampilan verifikasi pengajuan ijin guru. Pada tampilan ini kepala sekolah dapat melihat detail dan status terakhir pada pengajuan ijin. Pada tampilan ini juga kepala sekolah dapat membuat keputusan untuk menolak atau menyetujui ijin guru.

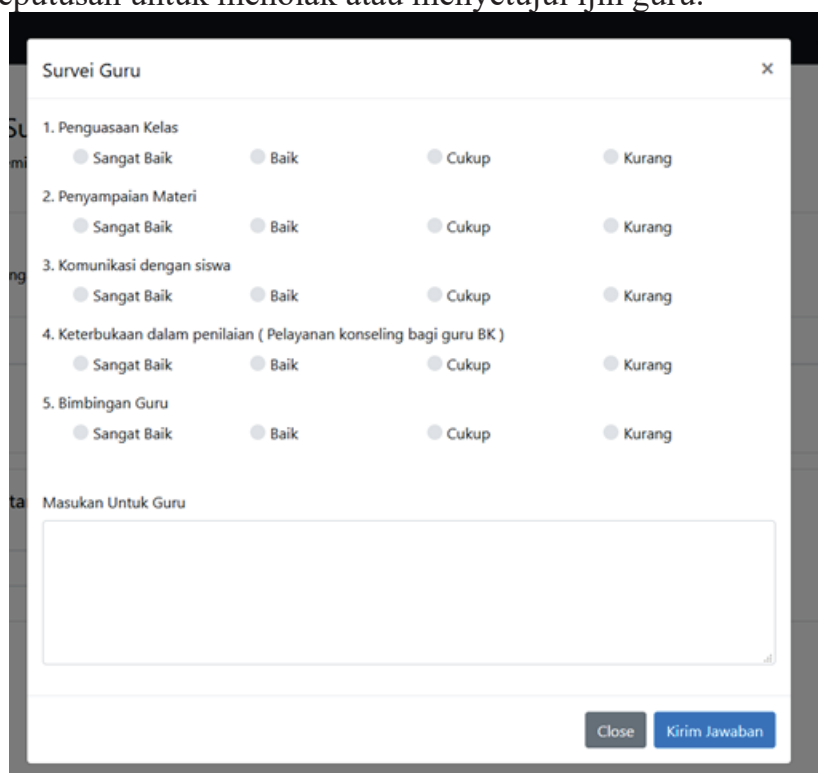

Gambar 51 Halaman Survei Guru

Pada Gambar 51 merupakan hasil implementasi form yang memungkinkan siswa untuk memberikan penilaian terhadap guru tertentu. Form survei akan muncul ketika siswa menekan tombol isi survei pada guru yang dipilih. Pada form ini siswa dapat memberikan nilai dengan 4 opsi yaitu Sangat Baik, Baik, Cukup dan Kurang untuk tiap-tiap pertanyaan. Selain memilih opsi, siswa juga dapat memberikan masukan kepada guru dengan menuliskannya pada kolom masukan yang disediakan

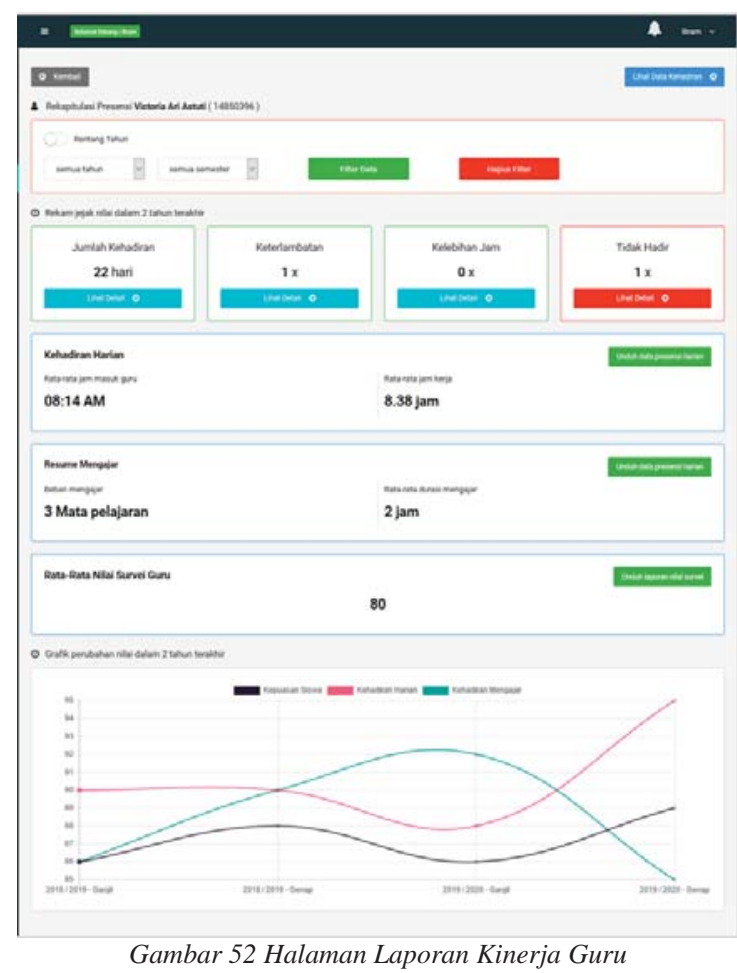

Pada Gambar 52 dijelaskan mengenai hasil implementasi halaman laporan kinerja guru. Pada halaman ini user dapat melihat beberapa rekapitulasi nilai guru dalam rentang waktu tertentu. Informasi yang ditampilkan dalam halaman ini adalah laporan presensi harian guru, laporan presensi mengajar guru dan visualisasi data berbentuk grafik dari hasil filter rentang waktu yang dipilih

\section{C.Penerapan Pengujian Sistem}

TABEL I

SKENARIO PENGUJIAN UNTUK WAKA KURIKULUM

\begin{tabular}{|l|l|l|}
\hline No & \multicolumn{1}{|c|}{ Skenario Pengujian } & \multicolumn{1}{|c|}{ Hasil yang diharapkan } \\
\hline 1 & Melakukan login & $\begin{array}{l}\text { User berhasil melakukan } \\
\text { login }\end{array}$ \\
\hline 2 & $\begin{array}{l}\text { Menambahkan mata } \\
\text { pelajaran }\end{array}$ & $\begin{array}{l}\text { User berhasil } \\
\text { menambahkan mata } \\
\text { pelajaran }\end{array}$ \\
\hline 3 & $\begin{array}{l}\text { Melakukan Registrasi } \\
\text { Guru }\end{array}$ & $\begin{array}{l}\text { User berhasil melakukan } \\
\text { registrasi guru }\end{array}$ \\
\hline 4 & $\begin{array}{l}\text { Menambahkan jadwal } \\
\text { mengajar guru }\end{array}$ & $\begin{array}{l}\text { User berhasil menambahan } \\
\text { jadwal mengajar guru }\end{array}$ \\
\hline 5 & $\begin{array}{l}\text { Melakukan setup survei } \\
\text { guru }\end{array}$ & $\begin{array}{l}\text { User berhasil melakukan } \\
\text { setup survei guru }\end{array}$ \\
\hline 6 & $\begin{array}{l}\text { Mengubah daftar } \\
\text { pertanyaan survei }\end{array}$ & $\begin{array}{l}\text { User berhasil mengubah } \\
\text { daftar pertanyaan survei }\end{array}$ \\
\hline
\end{tabular}

TABEL II

SKENARIO PENGUJIAN UNTUK GURU

\begin{tabular}{|l|l|l|}
\hline No & \multicolumn{1}{|c|}{ Skenario Pengujian } & \multicolumn{1}{c|}{ Hasil yang diharapkan } \\
\hline 1 & $\begin{array}{l}\text { Guru melakukan } \\
\text { presensi harian }\end{array}$ & $\begin{array}{l}\text { Guru berhasil melakukan } \\
\text { presensi harian }\end{array}$ \\
\hline
\end{tabular}




\begin{tabular}{|l|l|l|}
\hline 2 & $\begin{array}{l}\text { Guru melakukan } \\
\text { presensi mengajar }\end{array}$ & $\begin{array}{l}\text { Guru berhasil melakukan } \\
\text { presensi mengajar }\end{array}$ \\
\hline 3 & Guru melakukan login & $\begin{array}{l}\text { Guru berhasil melakukan } \\
\text { login }\end{array}$ \\
\hline 4 & Guru mengajukan ijin & $\begin{array}{l}\text { Guru berhasil mengajukan } \\
\text { ijin }\end{array}$ \\
\hline
\end{tabular}

TABEL III

SKENARIO PENGUJIAN UNTUK KEPALA SEKOLAH

\begin{tabular}{|l|l|l|}
\hline No & \multicolumn{1}{|c|}{ Skenario Pengujian } & \multicolumn{1}{|c|}{ Hasil yang diharapkan } \\
\hline 1 & User melakukan login & $\begin{array}{l}\text { User berhasil melakukan } \\
\text { login }\end{array}$ \\
\hline 2 & $\begin{array}{l}\text { Kepala sekolah } \\
\text { melakukan verifikasi ijin } \\
\text { guru }\end{array}$ & $\begin{array}{l}\text { Kepala sekolah berhasil } \\
\text { melakukan verifikasi ijin } \\
\text { guru }\end{array}$ \\
\hline
\end{tabular}

TABEL IV

SKENARIO PENGUJIAN UNTUK SISWA

\begin{tabular}{|l|l|l|}
\hline No & \multicolumn{1}{|c|}{ Skenario Pengujian } & \multicolumn{1}{|c|}{ Hasil yang diharapkan } \\
\hline 1 & $\begin{array}{l}\text { Melakukan verifikasi } \\
\text { data diri }\end{array}$ & $\begin{array}{l}\text { Siswa berhasil melakukan } \\
\text { verifikasi data diri }\end{array}$ \\
\hline 2 & $\begin{array}{l}\text { Mengisi form kuesioner } \\
\text { survei guru }\end{array}$ & $\begin{array}{l}\text { Siswa berhasil mengisi form } \\
\text { kuesioner survei guru }\end{array}$ \\
\hline
\end{tabular}

\section{D.Respon Pengguna Sistem}

TABEL V

RESPON WAKA KURIKULUM

\begin{tabular}{|l|l|l|l|}
\hline No & \multicolumn{1}{|c|}{$\begin{array}{c}\text { Skenario } \\
\text { Pengujian }\end{array}$} & \multicolumn{1}{|c|}{$\begin{array}{c}\text { Hasil yang } \\
\text { diharapkan }\end{array}$} & Respon \\
\hline 1 & Melakukan login & $\begin{array}{l}\text { User berhasil } \\
\text { melakukan login }\end{array}$ & Berhasil \\
\hline 2 & $\begin{array}{l}\text { Menambahkan } \\
\text { mata pelajaran }\end{array}$ & $\begin{array}{l}\text { User berhasil } \\
\text { menambahkan mata } \\
\text { pelajaran }\end{array}$ & Berhasil \\
\hline 3 & $\begin{array}{l}\text { Melakukan } \\
\text { Registrasi Guru }\end{array}$ & $\begin{array}{l}\text { User berhasil } \\
\text { melakukan registrasi } \\
\text { guru }\end{array}$ & Berhasil \\
\hline 4 & $\begin{array}{l}\text { Menambahkan } \\
\text { jadwal mengajar } \\
\text { guru }\end{array}$ & $\begin{array}{l}\text { User berhasil } \\
\text { menambahan jadwal } \\
\text { mengajar guru }\end{array}$ & Berhasil \\
\hline 5 & $\begin{array}{l}\text { Melakukan setup } \\
\text { survei guru }\end{array}$ & $\begin{array}{l}\text { User berhasil } \\
\text { melakukan setup } \\
\text { survei guru }\end{array}$ & Berhasil \\
\hline 6 & $\begin{array}{l}\text { Mengubah daftar } \\
\text { pertanyaan survei }\end{array}$ & $\begin{array}{l}\text { User berhasil } \\
\text { mengubah daftar } \\
\text { pertanyaan survei }\end{array}$ & Berhasil \\
\hline
\end{tabular}

TABEL VI

RESPON GURU

\begin{tabular}{|l|c|c|c|}
\hline No & $\begin{array}{c}\text { Skenario } \\
\text { Pengujian }\end{array}$ & $\begin{array}{c}\text { Hasil yang } \\
\text { diharapkan }\end{array}$ & Respon \\
\hline 1 & $\begin{array}{l}\text { Guru melakukan } \\
\text { presensi harian }\end{array}$ & $\begin{array}{l}\text { Guru berhasil } \\
\text { melakukan presensi } \\
\text { harian }\end{array}$ & Berhasil \\
\hline
\end{tabular}

\begin{tabular}{|l|l|l|l|}
\hline 2 & $\begin{array}{l}\text { Guru melakukan } \\
\text { presensi } \\
\text { mengajar }\end{array}$ & $\begin{array}{l}\text { Guru berhasil } \\
\text { melakukan presensi } \\
\text { mengajar }\end{array}$ & Berhasil \\
\hline 3 & $\begin{array}{l}\text { Guru melakukan } \\
\text { login }\end{array}$ & $\begin{array}{l}\text { Guru berhasil } \\
\text { melakukan login }\end{array}$ & Berhasil \\
\hline 4 & $\begin{array}{l}\text { Guru mengajukan } \\
\text { ijin }\end{array}$ & $\begin{array}{l}\text { Guru berhasil } \\
\text { mengajukan ijin }\end{array}$ & Berhasil \\
\hline
\end{tabular}

TABEL VII

RESPON KEPALA SEKOLAH

\begin{tabular}{|l|l|l|l|}
\hline No & \multicolumn{1}{|c|}{$\begin{array}{c}\text { Skenario } \\
\text { Pengujian }\end{array}$} & \multicolumn{1}{|c|}{$\begin{array}{c}\text { Hasil yang } \\
\text { diharapkan }\end{array}$} & Respon \\
\hline 1 & $\begin{array}{l}\text { User melakukan } \\
\text { login }\end{array}$ & $\begin{array}{l}\text { User berhasil } \\
\text { melakukan login }\end{array}$ & Berhasil \\
\hline 2 & $\begin{array}{l}\text { Kepala sekolah } \\
\text { melakukan } \\
\text { verifikasi ijin } \\
\text { guru }\end{array}$ & $\begin{array}{l}\text { Kepala sekolah } \\
\text { berhasil } \\
\text { melakukan } \\
\text { verifikasi ijin guru }\end{array}$ & Berhasil \\
\hline
\end{tabular}

TABEL VIII

RESPON SISWA

\begin{tabular}{|l|l|l|l|}
\hline No & \multicolumn{1}{|c|}{$\begin{array}{c}\text { Skenario } \\
\text { Pengujian }\end{array}$} & \multicolumn{1}{|c|}{$\begin{array}{c}\text { Hasil yang } \\
\text { diharapkan }\end{array}$} & Respon \\
\hline 1 & $\begin{array}{l}\text { Melakukan } \\
\text { verifikasi data } \\
\text { diri }\end{array}$ & $\begin{array}{l}\text { Siswa berhasil } \\
\text { melakukan } \\
\text { verifikasi data diri }\end{array}$ & Berhasil \\
\hline 2 & $\begin{array}{l}\text { Mengisi form } \\
\text { kuesioner survei } \\
\text { guru }\end{array}$ & $\begin{array}{l}\text { Siswa berhasil } \\
\text { mengisi form } \\
\text { kuesioner survei } \\
\text { guru }\end{array}$ & Berhasil \\
\hline
\end{tabular}

\section{E. Feedback Pengguna Sistem}

Pada bab ini dijelaskan mengenai timbal balik pengguna setelah melakukan pengujian dari skenario yang telah disediakan. Timbal balik akan dicatat dan digunakan sebagai acuan dalam perbaikan sistem. Adapun timbal balik pengguna sistem diantaranya adalah :

TABEL IX

FEEDBACK PENGGUNA SISTEM

\begin{tabular}{|l|l|}
\hline \multicolumn{1}{|c|}{ Waka Kurikulum } & \multicolumn{1}{c|}{ Guru } \\
\hline $\begin{array}{l}\text { Perlu diberikan pembeda } \\
\text { antara kolom opsional dan } \\
\text { wajib }\end{array}$ & $\begin{array}{l}\text { Tampilkan nama mata } \\
\text { pelajaran pada saat presensi } \\
\text { mengajar }\end{array}$ \\
\hline $\begin{array}{l}\text { Perlu dibuat sebuah alternatif } \\
\text { masukan lain apabila guru }\end{array}$ & $\begin{array}{l}\text { Ijin dibuat agar dapat di } \\
\text { verifikasi oleh petugas lain. } \\
\text { tidak memiliki NIP }\end{array}$ \\
Bukan hanya kepala sekolah \\
\hline
\end{tabular}

Pada sistem ini telah diterapkan salah satu masukan dari pengguna. Masukan tersebut yaitu pembuatan metode alternatif apabila guru tidak memiliki NIP. Gambar 53 menunjukkan sebelum dan sesudah masukan diterapkan ke dalam sistem. Masukan ini memberikan perubahan pada kolom input NIP ketika melakukan registrasi guru. Perubahan ini memungkinkan waka kurikulum untuk membuat ID baru bagi guru yang belum memiliki NIP. 


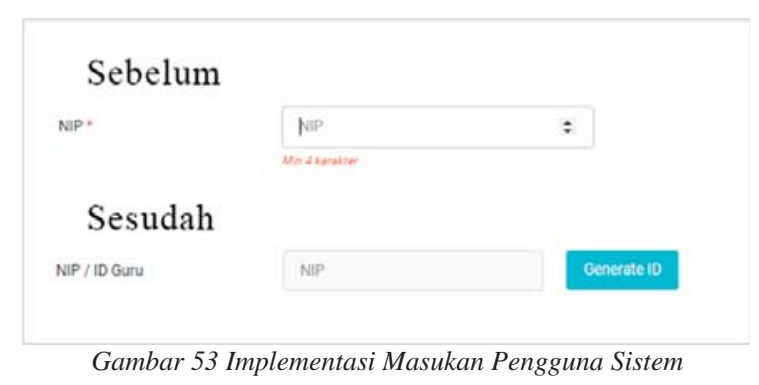

\section{F. Analisis Sistem}

Sistem Informasi Manajemen Kinerja Guru ini dibangun dengan tujuan untuk membantu proses evaluasi kinerja guru. Butir penilaian dalam evaluasi tersebut diantaranya adalah kehadiran harian, total jam mengajar dan nilai guru dari hasil survei siswa. Sistem ini dapat menjadi media dalam pengambilan presensi harian dan presensi mengajar secara digital melalui RFID maupun website. Selain presensi, sistem juga dapat menjadi media pengambilan nilai survei guru yang diisi oleh siswa.

Beberapa fitur pendukung lainnya yang diimplementasikan dalam sistem ini adalah adanya fitur pengajuan ijin. Ini memungkinkan guru untuk dapat mengajukan ijin secara digital apabila tidak dapat hadir ke sekolah. Pada fitur ini kepala sekolah juga diberikan hak akses untuk melakukan verifikasi terhadap pengajuan ijin guru. Seluruh data disimpan ke dalam satu database untuk diolah dan dijadikan sebuah laporan kinerja guru.

Dalam pembangunan Sistem Informasi Manajemen Kinerja Guru masih ditemui beberapa keterbatasan seperti belum adanya verifikasi siswa untuk kehadiran mengajar guru. Sistem juga belum memiliki batasan mengenai berapa kali guru dapat melakukan ijin dalam satu semester. Berikut merupakan kelebihan dan kekurangan sistem: Sistem memberikan fasilitas presensi harian guru secara digital; sistem memberikan fasilitas presensi mengajar guru secara digital; Sistem memberikan fasilitas bagi guru untuk mengajukan ijin ketidakhadiran; sistem memberikan fasilitas bagi siswa untuk mengisi form kuesioner evaluasi guru; dan sistem memberikan fasilitas bagi kepala sekolah untuk melihat nilai kinerja guru. Sedangkan kekurangan sistem adalah: belum ada verifikasi kehadiran guru dari sisi siswa; Metode input RFID masih memungkinkan terjadinya kecurangan presensi

\section{V.PENUTUP}

\section{A. Kesimpulan}

Berdasarkan hasil implementasi dan analisis Sistem Informasi Manajemen Kinerja Guru yang telah dibangun, maka dapat dibuat kesimpulan sebagai berikut :

1. Sistem dapat melakukan registrasi guru guna membantu kurikulum dalam melakukan pencatatan guru yang aktif mengajar di sekolah.

2. Sistem dapat menjadi media pencatatan presensi harian melaui RFID maupun website. Ini berguna untuk pencatatan presensi harian sehingga mampu didapatkan informasi mengenai tingkat kehadiran guru dalam tiap semester.

3. Sistem dapat menjadi media pencatatan presensi mengajar melalui RFID maupun website. Ini berguna untuk pencatatan presensi mengajar sehingga dapat diperoleh informasi mengenai beban mengajar dan total jam mengajar guru tiap semester.

4. Sistem mampu menjadi media pengambilan nilai guru melalui survei yang diisi oleh siswa.

5. Sistem dapat memberikan informasi berupa nilai dan visualisasi grafik rekam jejak untuk setiap perubahan nilai guru dalam setiap semester

6. Hasil pengujian sistem menunjukkan bahwa setiap responden berhasil melakukan tugas pada setiap skenario

\section{B. Saran}

Pada bab ini dijelaskan mengenai saran yang diberikan penulis apabila akan dilakukan pengembangan terhadap Sistem Informasi Manajemen Kinerja Guru. Penulisan saran ini mengacu pada respon dan feedback pengguna pada saat proses pengujian berlangsung. Adapun saran penulis diantaranya adalah :

1. Dapat dikembangkan sebuah metode verifikasi siswa ketika guru melakukan presensi mengajar.

2. Dapat dibuat batasan pengajuan ijin guru dalam kondisi tertentu. Contoh kasusnya adalah ketika guru sering tidak hadir maka akan terdapat notifikasi atau hilangnya hak akses guru untuk mengajukan ijin.

3. Metode input presensi RFID dapat diganti dengan Fingerprint agar lebih aman sehingga mencegah terjadinya kecurangan presensi

\section{UCAPAN TERIMA KASIH}

Pada penelitian tugas akhir ini, penulis mendapatkan bantuan, saran, semangat dan bimbingan dari banyak pihak. Oleh karena itu, penulis ingin mengucapkan banyak terima kasih kepada pihak-pihak yang telah terlibat dalam penelitian ini. Penulis ingin mengucapkan terima kasih kepada pihak SMA Bopkri 1 Yogyakarta karena telah bersedia menjadi mitra penulis dalam pengerjaan tugas akhir atau skripsi.

\section{DAFTAR PUSTAKA}

[1] Kementerian Pendidikan Nasional Republik Indonesia, Peraturan Menteri Pendidikan Nasional Republik Indonesia No.16, Kementerian Pendidikan Nasional Republik Indonesia, 2007.

[2] KEMENTERIAN PENDIDIKAN DAN KEBUDAYAAN REPUBLIK INDONESIA, PERATURAN MENTERI PENDIDIKAN DAN KEBUDAYAAN REPUBLIK INDONESIA NOMOR 28 TAHUN 2016 TENTANG SISTEM PENJAMINAN MUTU PENDIDIKAN DASAR DAN MENENGAH, KEMENTERIAN PENDIDIKAN DAN KEBUDAYAAN REPUBLIK INDONESIA, 2016.

[3] S. Sawchuk, "Teacher Evaluation: An Issue Overview," Education Week, 3 September 2015. [Online]. Available: https://www.edweek.org/ew/section/multimedia/teacherperformance-evaluation-issue-overview.html.

[4] T. M.Archer, "Web-Based Surveys," Journal of Extension, 21 Agusust 2003. [Online]. Available: https://www.joe.org/joe/2003august/tt6.php.

[5] D. Ingram, "What is Management Information System," Houston Chronicle, 12 February 2019. [Online]. Available: 
Windy Puji Oktiagraha, Umi Proboyekti, Yetli Oslan

https://smallbusiness.chron.com/management-informationsystem-2104.html.

[6] R. S.Pressman, Rekayasa Perangkat Lunak, Yogyakarta: Andi Publisher, 2015.

[7] R. Wulandari, Danuri dan Jaroji, "Aplikasi Pengelolaan Presensi Guru Berbasis Web di Dinas Pendidikan Kabupaten Bengkalis," Jurnal Informatika Polinema, p. 1, 2019.

[8] T. Robby, S. Djoni dan C. Ivan, "Penerapan Teknologi RFID untuk Purwarupa Pencatatan Presensi Mahasiswa di Laboratorium Komputer," Journal of Information Systems Engineering and Business Intelegence, p. 2, 2017.

[9] KEMENTERIAN PENDIDIKAN DAN KEBUDAYAAN

REPUBLIK INDONESIA, PERATURAN MENTERI PENDIDIKAN DAN KEBUDAYAAN REPUBLIK INDONESIA NOMOR 28 TAHUN 2016 TENTANG SISTEM PENJAMINAN MUTU PENDIDIKAN DASAR DAN MENENGAH, KEMENTERIAN PENDIDIKAN DAN KEBUDAYAAN REPUBLIK INDONESIA, 2016.

[10] R. d. L. E.Padmowati dan Akdon, "Sistem Manajemen Evaluasi Kinerja Guru dan Tenaga Kependidikan SMK," Universitas Katolik Parahyangan, Bandung, 2014. 